Reprinted from Wass, H. \& Myers, J. E. (1982). Psychosocial aspects of death among older persons:

A review of the literature. Personnel and Guidance Journal, 61 (3), 131-137. .

The American Counseling Association. Reprinted with permission.

No further reproduction authorized without written permission from the American Counseling Association.

\title{
Psychosocial Aspects of Death among the Elderly: A Review of the Literature
}

\author{
HANNELORE WASS \\ JANE E. MYERS
}

\begin{abstract}
Counselors who work with older persons often find it necessary to help them cope with concerns related to death and dying. They may become more effective facilitators by learning about psychosocial aspects of death and dying.
\end{abstract}

Death is an inescapable fact of life that touches everyone at some time. So all counselors, regardless of their work setting or clientele, will be faced with the need to help someone adjust to death, whether their own or the death of a parent, spouse, child, or friend. Helping old persons cope with death may be made easier for those counselors who are familiar with the known psychosocial aspects of death among the elderly. Therefore, the purpose of this article is to present a review of the research literature followed by a discussion of implications for counseling.

Theorists concerned with the psychology of aging have considered awareness of death, its increasing certainty, and its temporal nearness as central to their formulations (Butler, 1963; Cumming \& Henry, 1961; Erikson, 1950). Empirical study, however, has not been clearly based on these formulations. Rather, what we find is a whole array of studies, diverse in conceptualization and methodology, spanning almost three decades, that are difficult to sort out and integrate. Even so, we seem to have today the beginnings of a tentative knowledge base and a clearer understanding of the problems than we did before. This review is based on the existing literature on the following areas as they relate to the elderly: talking about death, death fears, dying, suicide, attitudes toward death, and bereavement.

\section{TALKING ABOUT DEATH}

Adult children find it difficult to broach the subject of death with their aging parents. Health care personnel in hospitals and nursing homes often manage to avoid the topic, sometimes resorting to bizarre behaviors and practices (Sudnow, 1967; Taylor, 1977). Until recently even experts on aging tended to avoid the subject (Wass \& Scott, 1977).

A number of studies, however, report that noninstitutionalized elderly persons think and talk readily about death (Beard, 1961; Jeffers, Nichols, \& Eisdorfer, 1961; Riley, 1968; Wass, 1977): Half of all institutionalized elderly persons are reported to talk about death in one study (Roberts, Kimsey, Logan, \& Shaw, 1970); another shows that elderly residents talk about death in a group situation (Saul \& Saul, 1973); and a third study reports that they talk about the subject frequently among themselves (Matse, 1975). Persons near death in geriatric fa- cilities make frequent positive references to death when given the opportunity (Kastenbaum, 1967).

Other studies have shown that nurses respond more slowly to the bell call from terminal patients than from nonterminal patients (Bowers, Jackson, Knight, \& LeShan, 1975). At regional, metropolitan, and geriatric hospitals and particularly in nursing homes, family visits are often very limited. This seems to be particularly the case when the dying period is protracted (Glaser \& Strauss, 1968). Thus, old persons often have little opportunity to talk with their loved ones about their impending death and to express their thoughts and feelings about it, and they obtain little emotional support from interaction with others. Many researchers have noted that old persons not only were willing to talk about their death but actually welcomed the opportunity (Feifel, 1959; Jeffers et al., 1961; Roberts et al., 1970; Saul \& Saul, 1973; Wass, 1977). In addition, advocates for older persons who are dying are pleading for better caring and support (Butler, 1975; Kübler-Ross, 1969; Roose, 1969; Saunders, 1972).

It seems, then, that in general both institutionalized and noninstitutionalized old persons think about death and are likely to talk about it when given the chance. These findings are consistent across several techniques of assessment using interview schedules, questionnaires, and observation. There are, of course, exceptions and particular situations in which the above does not hold true. A counselor quickly will discover these when working with an elderly client. The important thing is to establish clearly whether there is discomfort with the subject and if so, who is uncomfortable, the client or the counselor.

When we consider the study of death fears and attitudes, the picture is far less clear.

\section{DEATH FEARS}

Considerable research has been devoted to the study of death fears and their correlates. The terms death fear, death anxiety,

Hannelore Wass is a professor of educational psychology and an associate of the Center for Gerontological Studies at the University of Florida, Gainesville. Jane E. Myers is an assistant professor of guidance and counseling and Director of Rehabilitation Counselor Education at Ohio University, Athens. 
and death attitudes are often used interchangeably in the thanatological literature; yet important distinctions exist in psychological theories. "Fear" typically refers to a known specific object or event of which one is afraid. "Attitude" refers to an affective or cognitive orientation, either positive or negative, toward an object or event. "Anxiety" in the psychoanalytic tradition is a state of "felt" impending danger or threat that is unconscious, and various defense mechanisms, also unconscious, are used to keep it so. On the other hand; existential psychology views anxiety as an essential human characteristic, as "an individual's becoming aware that his existence can become destroyed" (May, 1958, p. 50).

Death fear has been conceptualized in a variety of ways: as unitary, as a continuum ranging from a negative feeling of fear to a positive feeling of joy, as a feeling that may comprise both negative and positive effect at the same time, as a two-dimensional entity having both cognitive and affective components, as a complex, multifaceted state, and as part of a larger search for meaning that varies not only from person to person but that changes within a person as he or she grows, matures, and confronts various life events. With such diversity of conceptualizations one should expect much contradiction in research results. The following brief review of some major findings in relation to death fears and correlates supports this contention. Studies in this area have been concerned with the assessment of death fears, attitudes, and anxieties and with the identification of factors and conditions associated with them.

Age

Lester (1972) found that age was not correlated with death fears, while others have found that young and middle-aged persons express more fear of death than those who are older (Bengtson, Cuellar, \& Ragan, 1977). As a group, aged persons seem to be less fearful of death than persons of younger age groups (Kalish \& Reynolds, 1977; Kastenbaum, 1969; Lieberman, 1965). The aged are a highly heterogeneous group, however, and considerable variation in death fears within elderly populations has been found.

\section{Sex}

Differences in death fears and attitudes among older men and women are reported as insignificant using projective techniques, interviews, and questionnaires (Christ, 1961; Rhudick \& Dibner, 1961; Swenson, 1961; Wass, Christian, Myers, \& Murphey, 1979). Lester (1972) and Wass and Sisler (1979) found women to have significantly greater death fears, based on use of rating scales.

\section{Ethnicity}

Although few studies have examined ethnic, factors with respect to older people and death fears, it has been found that Black elderly persons have higher death expectations (Butler, 1975; Hill, 1971), more familiarity with death (Kalish \& Reynolds, 1977), greater fear of violence (National Council on the Aging, 1975), and greater death concern (Kalish \& Reynolds, 1977; Myers, Wass, \& Murphey, 1980) as compared to white elderly persons.

\section{Health}

Most studies report that high levels of death fears are associated with individuals who report or who are observed to have poor physical and emotional health (Christ, 1961; Rhudick \& Dibner, 1961; Templer \& Dotson, 1970; Wass \& Sisler, 1979).

\section{Living Arrangements}

Older persons living in a community have been found to be less fearful of death than those living in institutions (Kimsey, Roberts, \& Logan, 1972). Residents living in an apartment complex showed less death fear as compared to those in the geriatric health care building of a large center for the elderly (Shrut, 1958). Less death anxiety was found among elderly dying persons in the community than among dying older persons who had recently been admitted to a nursing home or who were waiting to be admitted (Lieberman \& Coplan, 1970). Being institutionalized also seems to be associated with increased morbidity and mortality (Costello \& Tanaka, 1961; Killian, 1970; Lieberman, 1961; Markus, Blenkner, Blum, \& Downs, 1972), as does relocation from one's home to public housing (Brand \& Smith, 1974).

\section{Other Demographic Variables}

Studies of other demographic variables have yielded conflicting results. Low levels of formal education have been found to be related to negative death attitudes and high degrees of fears (Berman \& Hays, 1973; Riley, 1968; Swenson, 1961; Wass \& Sisler, 1979) or to have no relationship at all (Christ, 1961; Rhudick \& Dibner, 1961).

Similar discrepancies are found with respect to marital status and living arrangements. Some studies indicate that widowed elderly persons and those living alone have more negative death attitudes and more death fears than married elderly persons (Swenson, 1961; Wass \& Sisler, 1979). Others found no relationships (Rhudick \& Dibner, 1961). Socioeconomic background has shown up as a probable variable Jeffers et al., 1961) but the sample populations were nursing home residents or geriatric hospital patients, and it may well be that economic factors, social environment, and social status have become relatively unimportant for institutionalized old persons. Noninstitutionalized elderly persons with incomes of $\$ 15,000$ or more were found to have less death fear than those with incomes of $\$ 5,000$ or less. And rural elderly were found to be more fearful of death than their urban and suburban counterparts (Wass \& Sisler, 1979).

\section{Religiosity}

Comparison of religious beliefs and death fears among older people has produced the most conflicting results. Some findings indicate that religious old persons are less fearful than nonreligious old persons (Faunce \& Fulton, 1958; Jeffers et al., 1961; Martin \& Wrightsman, 1966). Other studies (Kalish \& Reynolds, 1977; Moberg, 1965; Swenson, 1961) report that only those with the most conservative and fundamental convictions and habits show relatively low death fear; still others discovered no relationship whatsoever between fear of death and religious belief or activities (Christ, 1961; Kurlychek, 1976; O'Reilly, 1958; Templer \& Dotson, 1970). It also has been found that fear of death is greater among religious than nonreligious old persons (Feifel; 1959; Wass \& Sisler, 1979).

\section{DYING}

The cultural and social contexts in which dying typically occurs are not something to anticipate with confidence and serenity. The discomfort and awkwardness of health professionals with the terminally ill, as indicated earlier, have been well-established empirically (Glaser \& Strauss, 1968; Sudnow, 1967; Weisman, 1972). While little change has been made to date (Quint-Benoliel, 1979), recent surveys suggest that nursing and medical schools increasingly offer courses, seminars, or discussion sessions on the topic of dying and death (Dickinson, 1976; Thrush, Paulus, \& Thrush, 1979). In fact, some exemplary programs of death education for health professionals have existed for years (Quint-Benoliel, 1982).

The hospice movement may have a positive influence on hospital care for dying persons (Davidson, 1978) and could greatly enhance the lives of nursing home residents (Butler, 1980). Such progress is important particularly for old dying patients since they experience the painful effects of age discrimination even in their dying days. Hospice care also extends to the home, a trend of particular significance since four out of every five people would prefer to die in their home (Hine, 1979).

The PERSONNEL AND GUIDANCE JOURNAL 
With respect to the intrapersonal dynamics of the dying process one theory that has received wide acceptance is the "five stages of dying" theory presented by Kübler-Ross (1969). Because the Kübler-Ross plea for more humanistic practices in terminal care has reached the hearts and minds of a great number of people (especially nurses) and made her famous, her theory of the five stages of dying has been religiously adopted and simplistically applied. A person's response to one's own dying, however, is far too complex to fit neatly into a model of a linear stepwise progression involving five single emotions from denial to acceptance. Even Kübler-Ross never claimed such oversimplification. Recently criticisms have been voiced and alternative models proposed (Kalish, 1978; Pattison, 1977; Rodabough, 1980; Shneidman, 1976).

Kastenbaum and Aisenberg (1976) have described the emerging roles of the mental health specialist with respect to the terminal patient. We underscore their statements especially with the dying old persons in mind.

Not many books are available on counseling and psychosocial services for the dying (Bowers et al., 1975; Garfield, 1978). Well over a hundred articles, however, on the subject have been published in various professional journals including two exclusively dealing with death (Death Education and Omega). It is beyond the scope of this paper to review these articles; however, such a review would provide a valuable service to the mental health worker.

\section{SUICIDE}

In the United States older persons comprise approximately $12 \%$ of the population, yet account for $25 \%$ of the reported suicides (Butler \& Lewis, 1973). That is over 10,000 deaths per year (Miller, 1979). These estimates are highly conservative since many suicides, particularly among aged persons, go unreported to protect the family and to retain insurance benefits. Most preventable suicides are related to depressive reactions resulting from loss, grief, loneliness, and despair (Butler \& Lewis, 1973).

Gerontologists and suicidologists generally agree that depression is wide-spread in old age (Birren, 1964; Busse \& Pfeiffer, 1969; Farberow \& Moriwaki, 1975; Farberow \& Shneidman, 1970; Miller, 1978). That should not surprise us. It takes enormous resources to cope with the accumulation of losses that many old persons experience. One study, for example, showed that bereaved persons who committed suicide had received less emotional support from their families and had a greater tendency to live alone than a matched nonsuicidal bereaved control group (Bunch, 1972).

In addition to losses through death, old persons have to cope with other significant losses: the loss of physical strength and stamina, health, income, social status and prestige, occupational and social roles, independence, and others. For many old people internal resources become weak and external resources are either not available or for various reasons not utilized. Without question older people are a speical at-risk group (Myers, Murphey, \& Riker, 1981), and suicide indicators are well established.

Butler and Lewis (1973) have identified the following factors as major diagnostic clues for suicide in old age (not listed in order of importance): depression, withdrawal, bereavement, isolation, expectation of death, induced helplessness, institutionalization, physical illness, meaninglessness of life, decreased self-regard, organic mental deterioration, changes in sleep patterns, and being male. They advise that counselors and other mental health workers be alert to these clues, to self-destructive behaviors such as alcoholism, abuse of prescribed or over-the-counter medication, not taking one's medication, and not eating properly, and to indirect verbal statements because old people often do not cry out for attention or threaten suicide; they just kill themselves. But; they apparently seek help before they do.
Miller (1979) reports the distressing finding that $77 \%$ of old persons he studied who committed suicide had seen a physician within a month of their death, and $29 \%$ within a week. Miller cites other studies with similar results. Butler and Lewis (1973) have provided excellent guidelines and suggestions for diagnostic assessment not only for potential suicides but for all other potential problem areas of particular relevance to the elderly. The interested reader is referred to their excellent book for more detail in this area.

A number of studies have discovered various other factors that may be associated with suicide, for example, approaching birthdays or anniversaries (Barraclough \& Sheperd, 1976; Bunch, 1975). In addition to considering special factors that may be contributive or causative to suicidal ideation and behavior in elderly persons, the pioneering work in the general assessment of self-destructive potentiality (Tabachnick \& Farberow; 1965) and emergency evaluation (Litman \& Farberow, 1965) should be consulted because it still is the best available in this area. Together with the consideration of recent theory (Farber, 1968) and treatment approaches (Shneidman, Farberow, \& Litman, 1970 ), these resources should prove a valuable basic reference for counselors and therapists.

It is unfortunate that the help offered by suicide prevention centers around the nation is not utilized by the elderly (Rachlis, 1970). The public and, according to Butler (1975), many professionals often believe that counseling and therapy are not helpful for aged persons when in fact they can be very effective. On the other hand, counselors may be confronted with a moral dilemma. McCartney (1978) has shown that persons with chronic, painful, and terminal illnesses, faced with the prospect of becoming totally dependent, tend to choose suicide rather than endure a situation they find intolerable. Jarvis and Boldt (1980) have provided evidence that physical illness was a contributing factor in the decision to suicide with increasing age. They suggest that approaches to suicide prevention among older people consider the role of the old person in the social system and take cognizance of his or her special needs and values. Other factors to consider are the family and social supports available to the older person (Lawrence, 1981) and death-related attitudes of older people, which are explored briefly below.

\section{ATTITUDES TOWARD DEATH}

Some old people may not experience a great deal of fear about death but no one has a neutral attitude toward it. It is virtually impossible for old persons to avoid the question of their personal death. There are simply too many reminders of our eventual fate as we grow old. Younger people often find it inconceivable that attitudes toward death can be positive, but this is actually the case for a good many old persons. Sick and very frail elderly, particularly those in adverse circumstances, may actually welcome death as a release. Death-related attitudes have been explored in a number of studies, and one area of considerable controversy concerns attitudes toward aggressive medical treatment for terminally ill old persons. Space limitation prevents a detailed discussion here.

The research literature concerning views on the right to die has been reviewed by Preston and Williams (1971) and more recently by Wass (1979). Since close family members are often too embarrassed to solicit their elders' views on these matters or feel it is harsh, cold, inappropriate, and so forth, counselors may be able to perform an important function. Old people have definite opinions on the issue of the right to die. By far the large majority wish to be allowed to die "naturally" rather than to be maintained by artificial or heroic means. In states that have "natural death" laws, a counselor may inform those who do not know of their right under the law. In states without such legislation (the large majority at present) it would be important to find out what an old person's wishes are. This knowledge should be shared with family and physician. It is 
likely to lessen considerably the anguish on the part of the family and physician should the situation occur when an old person in terminal condition is unable to communicate his or her wishes.

\section{BEREAVEMENT, GRIEF, AND MOURNING}

Technically speaking, bereavement refers to survivorship status, grief refers to the survivor's state of distress and response to loss; and mourning to the culturally accepted behaviors that express responses to death (Kastenbaum \& Costa, 1977). While both grief and mourning are expected of a bereaved person, there are social limitations placed on the duration and expression of sadness and loss. Socially and psychologically, the research literature suggests a distinction between normal and pathological grief (Clayton, 1979); however, death, particularly when it is sudden and unexpected, is a crisis state for everyone (Williams \& Polak, 1979).

Descriptions in the literature of "normal" grief are remarkably similar, indicating that a typical pattern of acute grief reaction does in fact exist (Lindemann, 1944) regardless of age. Uncomplicated grief, as defined by Engel (1961), runs a typical course modified by a select group of factors: the suddenness of the loss, preparation for the loss, if any, and the significance to the survivor of the lost person. Several authors (e.g., Clayton, Desmaris, \& Winokur, 1964; Engel, 1961; Gramlich, 1968) note that grief reactions closely parallel the stages postulated by Kübler-Ross (1969) in acceptance of death. In general, there is an initial phase of shock and denial, followed in a week or two by a stage of awareness. This stage is accompanied by feelings of sadness, guilt, helplessness, and hopelessness. In general, somatic, cognitive, affective, and behavioral reactions occur (Clayton, 1979; Engel, 1961). A prolonged phase of restitution and recovery eventually occurs, with acceptance of the loss and a return to a state of well-being and health, though the return may be impaired for older individuals, as discussed below.

Somatic grief reactions include disturbances in sleep, a tendency to sighing respiration, lack of strength and exhaustion, and loss of appetite (Clayton, 1979; Lindemann, 1944), conditions that may predispose elderly individuals to physical illness. Cognitive reactions include difficulty concentrating and loss of interest in previous activities.

The affective components of grief are exhaustive and include a variety of emotional reactions: anger, crying, hostility, depression, agitation, guilt, repression, and identification with the lost person (Clayton, 1979; Lindemann, 1944; Parkes, 1970; Switzer, 1970). The duration of these reactions depends on the success with which the bereaved individuals do their grief work. This involves acceptance of the loss, readjustment to the environment, and the formation of new relationships (Lindemann, 1944). These are often difficult tasks for older people due to a common reduction in social activity levels.

Abnormal grief reactions have been variously defined and described (e.g., Jacobs \& Douglas, 1979; Wahl, 1970). According to Lindemann (1944), morbid grief conditions result from distortions of normal grief, and include delayed reactions, distorted reactions, medical diseases, alterations in relationships with friends, hostility against specific persons, absence of emotional expression, loss of normal patterns of social interaction, self-punitive behavior, and agitated depression accompanied by symptoms such as insomnia and self-accusation. Other researchers, notably Bornstein, Clayton, Halikas, Maurice, and Robins (1973) caution against viewing severe depression as pathological, even after a period of time exceeding 1 year from the loss. An important point seems to be the differential diagnosis of normal and neurotic grief reactions (Wahl, 1970). In normal grief, three reactions are most apparent: depressed mood, sleep disturbance, and crying. These begin to abate 6 to 10 weeks after a death (Clayton, Desmaris \& Winokur, 1964).
Bornstein and Clayton (1972) suggest further the "anniversary reaction" as a good diagnostic indicator: If a person is significantly depressed 1 year from the date of the loss, the reaction may be one of clinical depression. Lack of treatment increases the potential for abnormal grief reactions among older people.

One process that seems to mitigate against abnormal grief reactions is that of anticipatory grief. Lindemann (1944) first defined this as the capacity to experience grief and accept a loss before the loss occurs. Recovery from grief is more rapid when a death is anticipated (Bornstein et al., 1973; Carey, 1977). Fulton and Gottesman (1980) reviewed this concept and its application in preventive psychiatry as a determinant of the severity of postmortem grief; they concluded that a reconsideration of the psychosocial aspects of anticipatory grief is needed. Other authors state that it is always present and that the issue is whether or not anticipatory grief has a positive effect on individual adjustment to loss. During the period of anticipatory grief, potentially hazardous forces exist that may be modified with effective intervention strategies (Gerber, Rusalem, Hannon, Battin, \& Arkin, 1975). In effect, then, the assumption that persons who are bereaved because of a death due to chronic illness will adjust better than those experiencing a sudden loss is not always valid.

Grief has been defined as a "self-limited process, requiring no medical attention" (Engel, 1961, p. 2). Yet, while no one ever died of grief, per se, research has shown that recently bereaved persons are more vulnerable to disease than nonbereaved persons (Parkes, 1964), especially when the death is sudden (Williams \& Polak, 1979). The health of widows is known to deteriorate following bereavement (Maddison \& Viola, 1968). In fact, a significant number of widowed persons die within 6 to 12 months following bereavement (Clayton, 1979; Parkes, 1970; Parkes, Benjamin, \& Fitzgerald, 1969; Wass, in press), perhaps because grief serves as a mediating process or bridge between a conjugal loss and an ensuing illness or death (Jacobs \& Douglas, 1979). It is important also to note the psychiatric effects of anniversary dates and the fact that many people die close to or at these individually significant dates, particularly persons who are middle-aged and older (Barraclough \& Sheperd, 1976).

Differences in the mourning process have been examined and findings indicate that mourning in aged persons is different from typical adult mourning (Skelskie, 1975). Grief is only one of many stresses experienced by old people (Cumming \& Henry, 1961); hence, it is more diffuse than in younger age groups and often completely obscured (Gramlich, 1968). A frequent occurrence in institutional settings, for example, is for grief reactions of older people to be misdiagnosed as symptoms of organic brain syndrome (Burnside, 1969).

Older people can and do adjust to loss and grief (Heyman \& Gianturco, 1973). Factors that correlate postively with the outcome of grieving include high economic status and high educational attainment (Glick, Weiss, \& Parkes, 1974).

\section{IMPLICATIONS FOR COUNSELORS}

While the plethora of research literature on psychosocial aspects of death and older people is impressive, the inconsistencies in findings in several areas, particularly in orientations toward death and dying, demonstrate the need for improvements. Research, theory, and practice should be closely aligned whenever possible, and the concepts discussed need more careful formulation and explication. A convergence of apparent conceptual conflicts should be sought as this will greatly benefit the research methodology used. In addition, carefully selected research designs may clarify the possible interaction of variables such as income, education, and other demographic and personal factors with death fear as well as other aspects of death, dying, and bereavement. Nevertheless, a number of implications for counseling practice are suggested from the

The PERSONNEL AND GUIDANCE JOURNAL 
existing literature and will be briefly outlined in this section. For a discussion of intervention strategies for bereavement, the reader is referred to the February 1981 Special "Loss" Issue of the Personnel and Guidance Journal.

The subject of dying and death, while no longer totally taboo in our society, still causes considerable dread or uneasiness, which one would like to avoid. Counselors working with clients in any of the areas discussed in this article first must become aware of their own feelings and attitudes toward death and the possibility of unresolved grief. They must be comfortable with their own feelings before they can be of assistance to others. The development of positive attitudes toward death is desirable (Wrenn, 1979). When working with older persons, counselors must come to terms with their attitudes toward aging (Huber \& Wolff, 1981) as well as dying and death.

Counselors who work with dying and bereaved persons will of necessity, find themselves in a dual role. First, they are a comforter and helper. Second, they will find themselves also to be in a bereaved state, and needing to adjust to the loss of a client (Wallace \& Townes, 1969). Moreover, as Lindemann (1944, p. 147) notes, "the essential task facing the...[helper] is that of sharing the [client's] grief work." Again, self-awareness and coming to terms with one's own feelings are of paramount concern.

Two major actions that may be taken to help ourselves and others are death education and participation in a bereavement service, either as a helper or as a client (Wass, in press). Death education may be formal or informal and may involve instruction from others or self-instruction. In addition to research reports and books, counselors will find it useful to discuss death with other counselors and caregivers and to learn from their experiences. Personal contact as a caregiver will provide further insight, and maximum development of the counselor will result when new experiences and learnings are shared with others. Support groups for counselors and other service providers are vital, especially when dealing with death and dying of older people (Dickel, 1981).

It also may be necessary for counselors to become educators for caregivers and family, to prevent mistakes made when expectations of behavior of terminal patients and bereaved survivors are based on an inadequate theory that may not apply to particular cases. To date no generally accepted theory of the psychosocial processes of dying has been formulated and empirically tested. There is general agreement, however, that we tend to segregate the dying physically, isolate them emotionally, treat them in a routinized manner, unmindful of their need to maintain personal dignity, interact with them as if they were incapable children, withhold important information, and generally keep communication to a minimum. Bereaved survivors are also treated in stereotypical fashion, often being avoided, with little tolerance for outward expressions of grief beyond a few months, or less.

Parkes (1979) concludes that it is easier to die than to survive. Bereavement services can be of great assistance to survivors in helping them to cope with and accept their losses and to develop new interests and relationships to replace those they have lost. A social support network of friends and helpers can be an effective resource to aid the adjustment process of bereaved persons, whether helpers or clients.

The widow-to-widow support program developed by Silverman $(1969,1970)$ is a model program begun in Boston and widely adopted elsewhere in the country. It is based on an understanding of grief as a process that has a beginning, a middle, and an end. The efficacy of self-help intervention for widows has received empirical support (Vachon, Lyall, Rogers, Freedman-Letofsky, \& Freeman, 1980). Counselors and other helpers may find their skills useful in organizing such programs in areas where none now exist.
Bereavement programs need not be limited to peer support. Parkes (1979) reported on an effective bereavement service involving the use of volunteers in a hospice setting. There are many other examples of support programs for older persons (Myers \& Salmon, in press).

Counselors dealing with dying and bereaved older people will find their entire repertoire of communication skills to be useful. Special attention should be given to nonverbal behavior, which will be an effective clue for clients concerning the counselor's attitudes toward and competence in dealing with issues related to death and dying. Warmth, empathy, and genuineness are paramount, as is true of any counseling interaction. Knowledge of assessment techniques will also prove useful. Given the conflicting nature of available research data, however, counselors are cautioned to develop their own diagnosfic devices for each particular client. The appropriate procedure in a specific case may vary considerably. A review and analysis of assessment in relation to death and dying are provided by Wass and Forfar (in press). Techniques useful in dealing with loss in general will be beneficial (Heikkinen, 1979)

Individual reactions to dying and death may also be expected to vary, and counselors must be flexible and tailor their approaches to the unique needs of the client and the circumstances. For example, as was noted earlier, reactions to bereavement vary depending on a number of factors such as the suddenness of death and whether or not the death was due to natural causes. Persons bereaved as a result of suicide face additional trauma beyond their immediate loss, including a fruitless search for blame (Silverman, 1972). Guidelines for working with persons in such circumstances include the need to focus on realistic acceptance of the death and relief of guilt feelings (Augenbraun \& Neuringer, 1970).

In working with older people, both those who are dying and those who survive, life review therapy is an effective intervention strategy (Butler, 1963). Through reminiscing with a helper, the dying person may be able to reconcile conflicts and become less fearful of death. For the survivor as well, the life review process can be a useful means for enhancing selfesteem (Waters \& Weaver, 1981). Additional suggestions for working with dying and bereaved older persons and their families are provided in recent publications by the American Personnel and Guidance Association (see Myers, 1981a, b).

\section{CONCLUSION}

A variety of counseling methods may be used in working with older persons. These are not limited to the approaches described here. They are limited only by the caring and creativity of the individual counselor. Key points to keep in mind include the interrelationship of the many factors discussed in this article (talking about death, death fears, dying, suicide, death related attitudes, grief, and mourning) and the uniqueness and individuality of each person. It is important to remember that grieving is a constructive process that results in a transition from one set of roles to another (Lindemann, 1976). This transition takes time, along with a sometimes painful trial-anderror approach, whether the grieving is for oneself or for others.

\section{REFERENCES}

Augenbraun, B., \& Neuringer, C. Helping survivors with the impact of a suicide. In A.C. Cain (Ed.), Suroivors of suicide. Springfield, Ill.: Charles C Thomas, 1970.

Barraclough, B.M., \& Sheperd, D.M. Birthday blues: The association of birthday with self-inflicted death in the elderly Acta Psychiatric Scandinavia, 1976, 54, 146-149.

Beard, B.B. Social adjustment in extreme old age. Cited by F.C. Jeffers C.R. Nichols, \& C. Eisdorfer, Attitudes of older persons toward death: A preliminary study. Journal of Gerontology, 1961, 16,-53-56.

Bengtson, V.L.; Cuellar, J.B.; \& Ragan, P.K. Stratum contrasts and similarities in attitudes toward death. Journal of Gerontology, 1977 $32,76-88$ 
Berman, A.L., \& Hays, J.E. Relationship between death anxiety, belief in afterlife, and locus of control. Journal of Consulting and Clinical Psychology, 1973, 41, 318.

Birren, J.E. The psychology of aging. Englewood Cliffs, N.J.: PrenticeHall, 1964.

Bornstein, P.E., \& Clayton, P.J. The anniversary reaction. Diseases of the Nervous System, 1972, 33, 470-472.

Bornstein, P.E.; Clayton, P.J.; Halikas, J.A.; Maurice, W.L.; \& Robins, E. The depression of widowhood after thirteen months. British Journal of Psychiatry, 1973, 122, 561-566.

Bowers, M.K.; Jackson, E.N.; Knight, J.A.; \& LeShan, L. Counseling the dying. New York: Jason Aronson, 1975

Brand, F.N., \& Smith, R.T. Life adjustment and relocation of the elderly. Journal of Gerontology, 1974, 29, 336-340.

Bunch, J. Recent bereavement in relation to suicide. Journal of Psychosomatic Research, 1972, 16, 361-366.

Bunch, M. Relationship between the month of birth and the month of death in the elderly. British Journal of Preventative Social Medicine, $1975,29,151-156$.

Burnside, I.M. Grief work in the aged patient. Nursing Forum, 1969, 8, 416-427.

Busse, E.W., \& Pfeiffer, E. (Eds.). Behavior and adaptation in late life. Boston: Little, Brown, 1969.

Butler, R.N. The life review: An interpretation of reminiscence in the aged. Psychiatry, 1963, 26, 65-76.

Butler, R.N. Why survive? Being old in America. New York: Harper \& Row, 1975.

Butler, R.N., \& Lewis, M.I. Aging and mental health. St. Louis: C.V. Mosby, 1973

Butler, R:N. A humanistic approach to our last days. Death Education, $1980,3,359-361$

Carey, R.G. The widowed: A year later. Journal of Counseling Psychology, $1977,24,125-131$.

Christ, P.E. Attitudes toward death among a group of acute geriatric psychiatric patients. Journal of Gerontology, 1961, 16, 56-59.

Clayton, P.J. The sequelae and nonsequelae of conjugal bereavement. American Journal of Psychiatry, 1979, 136, 1530-1534.

Clayton, P.; Desmaris, L.; \& Winokur, G. A study of normal bereavement. American Journal of Psychiatry, 1964, 125, 64-74.

Costello, J.P., \& Tanaka, G.M. Mortality and morbidity in long-term institutional care of the aged. Journal of the American Geriatrics Society, $1961,9,959-963$

Cumming, E., \& Henry, W.E. Growing old: The process of disengagement. New York: Basic Books, 1961.

Davidson, G.W. The hospice-Development and administration. Washing ton, D.C.: Hemisphere, 1978.

Dickel, C.T. Keeping up the good work. In J.E. Myers (Ed.), Counseling older persons: Volume II, Basic helping skills for service providers: Falls Church, Va.: APGA, 1981

Dickinson, G.E. Death education in U.S. medical schools. Journal of Medical Education, 1976, 51, 134-136

Engel, G.L. Is grief a disease? A challenge for medical research. Psychosomatic Medicine, 1961, 23 18-22.

Erikson, E.H. Childhood and society. New York: Norton, 1950.

Farber, M. Theory of suicide. New York: Funk \& Wagnall, 1968.

Farberow, N.L., \& Moriwaki, S.Y. Self-destructive crises in the older person. Gerontologist, 1975, 15, 333-337.

Farberow, N.L. \& Shneidman, E. Suicide and age. In E.S. Shneidman N.L. Farberow \& R.E. Litman (Eds.), The psychology of suicide. New York: Science House, 1970.

Faunce, W.A., \& Fulton, R.L. The sociology of death: A neglected area of research. Social Forces, 1958, 36, 205-209.

Feifel, H. Attitudes toward death in some normal and mentally ill populations. In $\mathrm{H}$. Feifel (Ed), The meaning of death. New York McGraw-Hill, 1959.

Fulton, R., \& Gottesman, D.J. Anticipatory grief: A psychosocial concept reconsidered. British Journal of Psychiatry, 1980, 137, 45-54.

Garfield, C.A. Psychosocial care for the dying patient. New York: McGrawHill, 1978.

Gerber, I.; Rusalem, R.; Hannon, N.; Battin, D.; \& Arkin, A. Anticipatory grief and aged widows and widowers. Journal of Gerontology $1975,30,225-229$

Glaser, B.G. \& Strauss, A.L. Time for dying. Chicago: Aldine, 1968.

Glick, I.O.; Weiss, R.S.; \& Parkes, C.M. The first year of bereavement. New York: Wiley, 1974.

Gramlich, E.P. Recognition and management of grief in elderly patients. Geriatrics, 1968, 23, 87-92

Heikkinen, C.A. Counseling for personal loss. Personnel and Guidance Journal, 1979, 58, 46-49.

Heyman, D.K., \& Gianturco, D.T. Long-term adaptation by the elderly to bereavement. Journal of Gerontology, 1973, 28, 359-362

Hill, R.B. A profile of black aged. In Minority aged in America. Detroit: University of Michigan-Wayne State University, 1971.

Hine, V.A. Dying at home: Can families cope? Omega, 1979-80, 10 175-180.
Huber, C., \& Wolff, A. Know thyself. In J.E. Myers (Ed.), Counseling older persons: Volume II, Basic helping skills. for service providers. Falls Church, Va.: APGA, 1981.

Jacobs, S., \& Douglas, L. Grief: A mediating process between a loss and illness. Comprehensive Psychiatry, 1979, 20, 165-176.

Jarvis, G.K., \& Boldt, M. Suicide in the later years. Essence, 1980, 4, 145-158.

Jeffers, F.C.; Nichols, C.R.; \& Eisdorfer, C. Attitudes of older persons toward death: A preliminary study. Journal of Gerontology, 1961, 16, 53-56.

Kalish, R.A., \& Reynolds, D.K. The role of age in death attitudes. Death Education, 1977, 1, 205-230.

Kalish, R.A. A little myth is a dangerous thing: Research in the service of the dying. In C.A. Garfield (Ed.), Psychosocial care of the dying patient. New York: McGraw-Hill, 1978.

Kastenbaum, R. The mental life of dying geriatric patients. Gerontologist, 1967, Pt. I, 97-100.

Kastenbaum, R. Death and bereavement in later life. In A.H. Kutscher (Ed.), Death and bereavement. Springfield, Ill.: Charles C Thomas, 1969

Kastenbaum, R., \& Aisenberg, R. The psychology of death. New York: Springer, 1976.

Kastenbaum, R., \& Costa, P.T. Psychological perspectives on death. Annual Review of Psychology, 1977, 28, 225-249.

Killian, E.C. Effects of geriatric transfer on mortality rates. Social Work $1970,15,19-26$.

Kimsey, L. Roberts, J.L.; \& Logan, D.L. Death, dying, and denial in the aged. American Journal of Psychiatry, 1972, 129, 161-166.

Kübler-Ross, E. On death and dying. New York: Macmillan, 1969.

Kurlychek, R.T. Level of belief in afterlife and four categories of fear of death in a sample of $60+$ year-olds. Psychological Reports, 1976 $38,228$.

Lawrence, P. Applying skills with special populations. In J.E. Myers (Ed.), Counseling older persons: Volume II, Basic helping skills for service providers. Falls Church, Va.: APGA, 1981.

Lester, D. Studies in death attitudes: Part two. Psychological Reports $1972,30,440$

Lieberman, M.A. Relationship of mortality rates to entrance to a home for the aged. Geriatrics, 1961, 16, 515-519.

Lieberman, M.A. Psychological correlates of impending death: Some preliminary observations. Journal of Gerontology, 1965, 20, 182-190.

Lieberman, M.A., \& Coplan, A.S. Distance from death as a variable in the study of aging. Developmental Psychology, 1970, 2, 71-84.

Lindemann, E. Symptomatology and management of acute grief American Journal of Psychiatry, 1944, 10, 141-148.

Lindemann, E. Grief and grief management: Some reflections. Journal of Pastoral Care, 1976, 39, 198-207.

Litman, R.E., \& Farberow, N.L. Emergency evaluation of self-destructive potentiality. In N.L. Farberow \& E.S. Shneidman (Eds.), The cry for help. New York: McGraw-Hill, 1965.

Maddison, D., \& Viola, A. The health of widows in the year following bereavement. Journal of Psychosomtic Research, 1968, 12, 297-306.

Markus, E.; Blenkner, M.; Blum, M.; \& Downs, T. Some factors and their association with post relocation mortality among institution alized aged persons. Journal of Gerontology, 1972, 27, 276-382.

Martin, D., \& Wrightsman, L.S. The relationship between religious behavior and concern about death. Journal of Social Psychology, 1966, $65,317-324$.

Matse, J. Reactions to death in residential homes for the aged. Omega, $1975,6,21-32$

May, R. Contributions of existential psychotherapy. In R. May, E. Angel, \& H.F. Ellenberg (Eds.), Existence: A new dimension in psychiatry and psychology. New York: Basic Books, 1958.

McCartney, J.R. Suicide vs. the right to refuse treatment. Psychosomatics, $1978,19,548-551$

Miller, M. Geriatric suicide: The Arizona study. Gerontologist, 1978, 18, 488-495.

Miller, M. Suicide after sixty-The final alternative. New York: Springer Publishing, 1979.

Moberg, O.O. Religiosity in old age. Gerontologist, 1965, 5, 78-87.

Myers, J.E. (Ed.), Counseling older persons, Volume II: Basic helping skills for service providers in aging. Falls Church, Va.: APGA, 1981.(a)

Myers, J.E. (Ed.), Counseling older persons, Volume III: A trainer's manual for basic helping skills. Falls Church, Va.: APGA, 1981.(b)

Myers, J.E., \& Salmon, H.E. Counseling programs for older people: Status, shortcomings and potentialities. Counseling Psychologist, in press.

Myers, J.E.; Murphey, M.; \& Riker, H.C. Mental health needs of older persons: Identifying at-risk populations. American Mental Health Counselors Association Journal, 1981, 3, 53-61.

Myers, J.E.; Wass, H.; \& Murphey, M., Jr. Ethnic differences in death anxiety among the elderly. Death Education, 1980, 4, 237-244.

National Council on the Aging: The myth and reality of aging in America. Washington, D.C.: Author, 1975. 
O'Reilly, C.T. Religious practice and personal adjustment. Sociology and Social Research, 1958, 42, 119-121.

Parkes, C.M. Effects of bereavement on physical and mental health. British Medical Journal, 1964, 2, 274-279.

Parkes, C.M. The first year of bereavement. Psychiatry, 1970, 33, 444467.

Parkes, C.M. Evaluation of a bereavement service. In A. deVries \& A. Carmi (Eds.), The dying human. Ramat Gan, Israel: Turtledove, 1979.

Parkes, C.M.; Benjamin, B.; \& Fitzgerald, R.G. Broken heart: A statistical study of increased mortality among widowers. British Medical Journal, 1969, 1, 740-743.

Pattison, E. The experience of dying. Englewood Cliffs, N.J.: PrenticeHall, 1977.

Preston, C.E., \& Williams, R.H. Views of the aged on the timing of death. Gerontologist, 1971, Part I, 300-304.

Quint-Benoliel, J. Dying in institutions. In H. Wass (Ed.), DyingFacing the facts. New York: McGraw-Hill and Hemisphere, 1979.

Quint-Benoliel, J. (Ed.). Death education for health professionals. Death Education. New York: Hemisphere \& McGraw Hill, Int., 1982.

Rachlis, D. Suicide and loss adjustment in the aging. Bulletin of Suicidology, 1970, 23-26.

Rhudick, P.I., \& Dibner, A.S. Age, personality, and health correlates of death concern in normal aged individuals. Journal of Gerontology, $1961,16,44-50$

Riley, J.W. Attitudes toward death. In M.W. Riley, A. Foner, \&. Associates (Eds.), Aging and society, Vol. I: An inventory of research findings. New York:: Russell Sage Foundation, 1968.

Roberts, J.; Kimsey, L.; Logan, D.; \& Shaw, G. How aged in nursing homes view dying and death. Geriatrics, 1970, 25, 115-119.

Rodabough, T. Alternatives to the stages model of the dying process. Death Education, 1980, 4, 1-19.

Roose, L.J. To die alone. Mental Hygiene, 1969, 53, 321-326.

Saul, S.R., \& Saul, S. Old people talk about death. Omega, 1973, 4, 27-35.

Saunders, C. The last stages of life. In M.A. Browning \& E.P. Lewis (Eds.), The dying patient. New York: The American Journal of Nursing Co., 1972.

Shneidman, E.S. Death: Current perspectives. Palo Alto, Calif.: Mayfield, 1976

Shneidman, E.S.; Farberow, N.L.; \& Litman, R.E: Psychology of suicide. New York: Science House, 1970.

Shrut, S.D. Attitudes toward old age and death. Mental Hygiene, 1958, 42, 259-266.

Silverman, P.R. The widow-to-widow program: An experiment in preventive intervention. Mental Hygiene, 1969, 53, 333-337.

Silverman, P.R. The widow as a caregiver in a program of preventive intervention with other widows. Mental Hygiene, 1970, 54, 540-546.

Silverman, P.R. Intervention with the widow of a suicide. In A.C. Cain (Ed.), Survivors of suicide. Springfield, Ill.: Charles C Thomas, 1972.

Skelskie, B.E. An exploratory study of grief in old age. Smith College Studies in Social Work, 1975, 45, 159-182.
Sudnow, D. Passing on-The social organization of dying. Englewood Cliffs, N.J.: Prentice-Hall, 1967.

Swenson, M.W. Attitudes toward death in an aged population. Journal of Gerontology, 1961, 16, 49-52.

Switzer, D.K. Dynamics of grief: Its sources, pain and healing. Nashville, Tenn.: Abingdon, 1970 .

Tabachnick, N.D., \& Farberow, N.L. The assessment of self-destructive potentiality. In N.L. Farberow \& E.S. Shneidman (Eds.), The cry for help. New York: McGraw-Hill 1965.

Taylor, C. Death, American style. Death Education, 1977, 1, 177-185.

Templer, D.I., \& Dotson, E. Religious correlates of death anxiety. Psychological Reports, 1970, 26, 895-897.

Thrush, I.C.; Paulus, G.S.; \& Thrush, P.I. The availability of education on death and dying: A survey of U.S. nursing schools. Death Education, 1979, 3, 131-142.

Vachon, M.L.S.; Lyall, W.A.L.; Rogers, J.; Freedman-Letofsky, K.; \& Freeman; S.J.J. A controlled study of self-help intervention for widows. American Journal of Psychiatry, 1980, 137, 1380-1384.

Wahl, C.W. The differential diagnosis of normal and neurotic grief following bereavement. Psychosomatic, 1979, 10, 104-106.

Wallace, E., \& Townes, B.D. The dual role of comforter and bereaved. Mental Hygiene, 1969, 53, 327-332.

Wass, H. Views and opinions of elderly persons concerning death. Educational Gerontology, 1977, 2, 15-26.

Wass, H. Death and the elderly. In H. Wass (Ed.), Dying-Facing the facts. New York: Hemisphere and McGraw-Hill, 1979.

Wass, H. Death: The final stage of life. In R.H. Sherron \& D.B. Lumsden (Eds.), Introduction to educational gerontology (2nd ed.). New York: Hemisphere Publishing Co., in press.

Wass, H.; Christian, M.; Myers, J.; \& Murphey, M., Jr. Similarities and dissimilarities in attitudes toward death in a population of older persons.' Omega, 1979, 9, 337-354.

Wass, H. \& Forfar, C.S. Assessment of attitudes toward death: techniques and instruments for use with older people. Measurement and Evaluation in Guidance, in press.

Wass, H., \& Scott, M. Aging without death? Gerontologist, 1977, 17, $377-390$.

Wass, H., \& Sisler, H.H. Death concern and views on various aspects of dying among elderly persons. In A. deVries \& A. Carmi (Eds.) The dying human. Ramat Gan, Israel: Turtledove, 1979

Waters, E., \& Weaver, A. Specialized techniques to help older people. In J.E. Myers (Ed.), Counseling older persons: Volume III, A trainer's manual for basic helping skills. Falls Church, Va.: APGA, 1981.

Weisman, A.D. On dying and denying. New York: Behavioral Publications, 1972 .

Williams, W.V., \& Polak, P.R. Follow-up research in primary prevention: A model of adjustment in acute grief. Journal of Clinical Psychology, 1979, 35, 35-45.

Wrenn, C.G. Caring for others when they need you most. Humanist Educator, 1979, 18, 98-106. 